\title{
Matrilysin Expression and Function in Airway Epithelium
}

\author{
Sarah E. Dunsmore, ${ }^{\star}$ Ulpu K. Saarialho-Kere, ${ }^{\star}$ Jill D. Roby, ${ }^{\star}$ Carole L. Wilson, ${ }^{\star \ddagger}$ Lynn M. Matrisian, ${ }^{\S}$ Howard G. Welgus, ${ }^{\star}$ \\ and William C. Parks ${ }^{\star \ddagger}$ \\ *Department of Medicine (Dermatology) and ${ }^{\ddagger}$ Department of Cell Biology and Physiology, Washington University School of Medicine, \\ St. Louis, Missouri 63110; and ${ }^{\S}$ Department of Cell Biology, Vanderbilt University School of Medicine, Nashville, Tennessee 37232
}

\begin{abstract}
We report that matrilysin, a matrix metalloproteinase, is constitutively expressed in the epithelium of peribronchial glands and conducting airways in normal lung. Matrilysin expression was increased in airway epithelial cells and was induced in alveolar type II cells in cystic fibrosis. Other metalloproteinases (collagenase-1, stromelysin-1, and $92-\mathrm{kD}$ gelatinase) were not produced by normal or injured lung epithelium. These observations suggest that matrilysin functions in injury-mediated responses of the lung. Indeed, matrilysin expression was increased in migrating airway epithelial cells in wounded human and mouse trachea. In human tissue, epithelial migration was reduced by $>80 \%$ by a hydroxamate inhibitor, and in mouse tissue, reepithelialization in trachea from matrilysin-null mice was essentially blocked. In vivo observations and cell culture studies demonstrated that matrilysin was secreted lumenally by lung epithelium, but upon activation or while migrating over wounds, some matrilysin was released basally. The constitutive production of matrilysin in conducting airways, its upregulation after injury, its induction by alveolar epithelium, and its release into both lumenal and matrix compartments suggest that this metalloproteinase serves multiple functions in intact and injured lung, one of which is to facilitate reepithelialization. (J. Clin. Invest. 1998. 102:1321-1331.) Key words: trachea $\bullet$ pulmonary alveoli $\bullet$ wound healing $\bullet$ cell polarity • cell migration
\end{abstract}

\section{Introduction}

Repair involves an orderly progression of events to reestablish the integrity of the injured tissue. The initial injury sets off a programmed series of interdependent yet separate responses, such as reepithelialization and epithelial proliferation, inflammation, angiogenesis, fibroplasia, matrix accumulation, and eventually resolution. During each stage in this process, proteinases are needed to remove or remodel extracellular matrix components in both the epithelial and interstitial compartments, in part to accommodate cell migration and other ongo-

Address correspondence to William C. Parks, Ph.D., Dermatology Division, Barnes-Jewish Hospital, 216 S. Kingshighway Blvd., St. Louis, MO 63110. Phone: 314-454-7543; FAX: 314-454-5372; E-mail: bparks@imgate.wustl.edu

Received for publication 18 August 1997 and accepted in revised form 9 August 1998.

J. Clin. Invest.

(C) The American Society for Clinical Investigation, Inc. 0021-9738/98/10/1321/11 \$2.00

Volume 102, Number 7, October 1998, 1321-1331

http://www.jci.org ing events (1). For example, we have shown that the activity of epidermal-derived collagenase-1 (MMP-1), a member of the matrix metalloproteinase (MMP) ${ }^{1}$ gene family, is required for reepithelialization of cutaneous wounds (2). Using lung as a model, we assessed if MMP-1 in the skin provides a paradigm of the proteolytic needs of reepithelialization in other tissues. Our findings, summarized here, demonstrate that in lung, matrilysin (MMP-7), which is not expressed in skin wounds, is required for repair of airway epithelial injuries. These observations indicate that distinct MMPs function in the repair of different epithelial tissues.

MMPs comprise a subgroup of the much larger family of zinc-dependent metalloproteinases (3). This subgroup is called "matrix metalloproteinases" because numerous biochemical studies have demonstrated that all members can degrade matrix proteins, and as a group, MMPs have the combined ability to degrade essentially all connective tissue components $(4,5)$. Because of their extensive catalytic potential, MMPs are involved in normal biological processes associated with connective tissue turnover, such as morphogenesis, uterine involution, bone resorption, and wound repair (5-9), but they can be over-produced in response to disease processes associated with inflammation, such as arthritis $(10)$, atherosclerosis $(11,12)$, fibrosis (13), and chronic ulceration (14). Overall, the production of MMPs is regulated, temporally limited, and occurs in response to specific signals.

Matrilysin, the smallest known MMP (28 kD), lacks the $\mathrm{COOH}$-terminal hemopexin-like domain contained by all other MMPs (15), which is thought to restrict substrate specificity (4). Still, matrilysin has all of the general characteristics of MMPs, such as being secreted in a latent form and being inhibited by TIMPs. Matrilysin has a broad substrate specificity, being able to degrade elastin, proteoglycans, type IV collagen, fibronectin, entactin/nidogen, the core protein of proteoglycans $(12,16,17)$, and other components found in lung matrix. In addition, matrilysin effectively cleaves and inactivates $\alpha 1-$ antitrypsin (18), thereby providing an indirect mechanism by which this MMP can participate in matrix remodeling.

Matrilysin is produced in a regulated manner by blood monocytes $(19,20)$ and, at least in atherosclerotic lesions, by tissue macrophages (12). Unlike most MMPs, however, matrilysin is constitutively expressed by epithelial cells, often ductal epithelium, in most, if not all adult exocrine glands. For example, matrilysin is produced by all skin and salivary glands, by ductal epithelium of pancreas, liver, and breast, and by the glandular epithelium of the intestine and reproductive organs (21-24). However, matrilysin is not expressed by all epithelial cells, being absent in mature epidermis $(23,25)$. Expression of matrilysin is markedly upregulated in the epithelium bordering ulcerations in the small intestine (26), and this observation,

1. Abbreviations used in this paper: $\mathrm{CF}$, cystic fibrosis; MMP, matrix metalloproteinase. 
along with the constitutive expression in intact glands, suggests that this MMP serves separate roles in the repair and homeostasis of epithelium. Furthermore, matrilysin is expressed by neoplastic cells in many forms of adenocarcinoma (15), and deficiency of this MMP delays development of intestinal neoplasms (27) indicating a role in oncogenesis.

We report here that matrilysin is constitutively expressed in adult human lung by ciliated cells of conducting airways and by ductal and serous epithelial cells of peribronchial glands. Earlier studies showed by Northern hybridization that matrilysin is expressed in normal and malignant lung $(28,29)$, but the cell source of this mRNA was not determined. Because epidermal-derived MMPs are expressed during active periods of reepithelialization in the skin $(7,30)$, we assessed if the pattern of matrilysin expression would be altered in inflammatory lung disease and in response to injury. We found that matrilysin expression is elevated in airway epithelium and induced in alveolar type II cells in lungs from patients with cystic fibrosis (CF). These findings suggest that matrilysin is upregulated in response to injury, perhaps to facilitate epithelial cell migration, and indeed, repair of injured tracheal epithelium was impaired in matrilysin-null mice. Our results provide evidence of in vivo production of a specific matrix-degrading proteinase (matrilysin) by airway epithelial cells and suggest that matrilysin is the predominant MMP controlling repair of the lung epithelium.

\section{Methods}

Tissues. Formalin-fixed, paraffin-embedded archival specimens were obtained from the Department of Pathology, Washington University School of Medicine. For normal lung, we obtained samples taken from tumor-free margins of tissue removed during lobectomy of patients with cancer $(n=4)$ or from recipient lungs of transplant patients with primary pulmonary hypertension $(n=6)$. For diseased lung, we examined CF $(n=12)$, organizing pneumonia $(n=4)$, adenocarcinoma $(n=4)$, and sarcoidosis $(n=2)$. For organ culture studies, a segment of the proximal end of normal human trachea was obtained from donor lungs $(n=4)$ at the time of transplant. Mouse tracheas were isolated from 7-wk-old matrilysin-null $\mathrm{N}_{10}$ female mice (>99\% C57BL/6) and wild-type age- and strain-matched littermates. Matrilysin-deficient mice were generated as described (27).

In situ hybridization. In vitro transcribed antisense and sense RNA probes for matrilysin, collagenase-1, stromelysin-1, and 92-kD gelatinase were labeled with $\left[\alpha-{ }^{35}\right.$ S $]$ UTP as described (7). The specificity of these probes for their specific mRNA has been characterized $(7,19,30,31)$. Sections were hybridized with ${ }^{35}$ S-labeled RNA probes $\left(4 \times 10^{4} \mathrm{cpm} / \mu\right.$ l hybridization buffer $)$ and were washed under stringent conditions, including treatment with RNase A, as described (32). After autoradiography for 14-21 d, the photographic emulsion was developed, and the slides were stained with hematoxylin and eosin. In situ hybridization experiments were done at least twice.

Immunohistochemistry. Anti-human matrilysin antiserum was raised in rabbits against a synthetic peptide corresponding to amino acids $93-108$, and, as shown previously, this antibody specifically recognizes both the $28-\mathrm{kD}$ zymogen and the 19-kD activated forms of matrilysin (19). For immunohistochemistry, antimatrilysin antibodies were affinity purified from immune serum. For this, BSA-conjugated synthetic peptide, which was also used for immunization, was coupled to Affi-Gel 100 (Bio-Rad, Richmond, CA), and antimatrilysin antibodies were adsorbed to the column as described (33). Essentially all immunoreactivity, as assessed by immunoblotting to purified enzyme (19), was eluted with $0.2 \mathrm{M}$ glycine, $\mathrm{pH}$ 2.3. Neutralized fractions were pooled and adjusted to the original volume of serum added to the column. A rabbit polyclonal antibody was generated against a fu- sion protein containing glutathione- $S$-transferase coupled to the 40 COOH-terminal amino acids of mouse matrilysin as described (27). Pan-cytokeratin antibody (AE-1 and AE-3) was obtained from BioGenex (San Ramon, CA).

Deparaffinized 5- $\mu \mathrm{m}$ sections were processed for immunohistochemistry using alkaline phosphatase or horseradish peroxidase detection systems as described (7). Endogenous peroxidase activity was blocked by incubation in $0.3 \% \mathrm{H}_{2} \mathrm{O}_{2}$ for $30 \mathrm{~min}$ at room temperature. Affinity-purified anti-human matrilysin antibody was diluted 1:1,000, and anti-mouse antibody was used at 1:500. Bound antibody was detected using the appropriate Vectastain ABC Elite kit (Vector Laboratories, Inc., Burlingame, CA) following the manufacturer's instructions. Peroxidase activity was detected using $3,3^{\prime}$-diaminobenzidine tetrahydrochloride as chromogenic substrate. Sections were counterstained with Harris hematoxylin. For negative controls, sections were processed with preimmune serum or, for the anti-human antibody, were incubated with affinity-purified antibodies in the presence of excess peptide antigen $(5 \mu \mathrm{g} / \mathrm{ml})$ to inhibit specific interactions with matrilysin in the tissue.

Tracheal wound studies. Human tracheal rings were dissected into $1-\mathrm{cm}^{3}$ pieces. Mouse tracheas $(5 \mathrm{~mm}$ in length) were removed and were cut longitudinally to expose the epithelial surface. Using a cell scraper (3010; Corning Costar Corp., Cambridge, MA), we made a uniform 1.5-mm-wide wound across the width of both human and mouse tracheal specimens. In other experiments, no wound was created, but rather we tracked tracheal epithelial migration, or epiboly, along the cut edges of the tissue pieces. Individual pieces of trachea were placed into the wells of 6-well cluster dishes and covered with DME containing 5\% FCS and antibiotics. A peptide hydroxamate metalloproteinase inhibitor, SC44463 (34) (Monsanto Corp., St. Louis, $\mathrm{MO}$ ), was added at a concentration of $25 \mu \mathrm{M}$ to some wounded human tracheal explants. At the indicated time ( $12 \mathrm{~h}$ to $5 \mathrm{~d})$, tissues were fixed in $10 \%$ buffered formalin and processed for paraffin embedding. Sections were stained with hematoxylin and eosin or with antibody against cytokeratin or mouse or human matrilysin. On tracheas wounded with the cell scraper, reepithelialization was quantified by measuring the length of the denuded wound area at various times after injury.

Matrilysin secretion. Primary alveolar type II pneumocytes were isolated from adult rat lungs as described in detail (35). CaLu-3 (human lung adenocarcinoma, HTB-55) and WiDr (human colorectal adenocarcinoma, CCL-218) cell lines were obtained from the American Type Culture Collection (Rockville, MD). To assess vectorial secretion of matrilysin, cells were plated onto transwell inserts of tissue culture-treated polyethylene terephthalate membrane (0.4- $\mu \mathrm{m}$ pore) and grown to confluence. The integrity of the monolayer was verified by measuring the resistance across the epithelial layer using an EVOM Epithelial Voltohmmeter (World Precision Instruments, Inc., Sarasota, FL). Experiments were begun when the resistance across the epithelial monolayer was $\geq 200 \Omega$, which was typically reached 3-4 d after plating. The resistance across a transwell with no cells was $100 \Omega$. Some type II cultures were treated with $5 \times 10^{-9} \mathrm{M}$ PMA, and $48 \mathrm{~h}$ later, medium was collected from both the upper and lower chamber and analyzed by casein zymography (12). Matrilysin secretion from human cell lines was assessed in 72-h conditioned medium by immunoblotting using enhanced chemiluminescence.

\section{Results}

Matrilysin is expressed in intact airway epithelium. In all samples of human lung, whether normal or diseased, staining for matrilysin protein was seen in epithelial cells lining peribronchial glands and conducting airways (Fig. 1). For normal tissue, we used sections of lung from patients with primary pulmonary hypertension (see Figs. 1, $2 a, 2 b$, and $3 e$ ) and the tumorfree margins of resected cancers. Because pulmonary hypertension is a vascular condition, airways in hypertensive lungs 

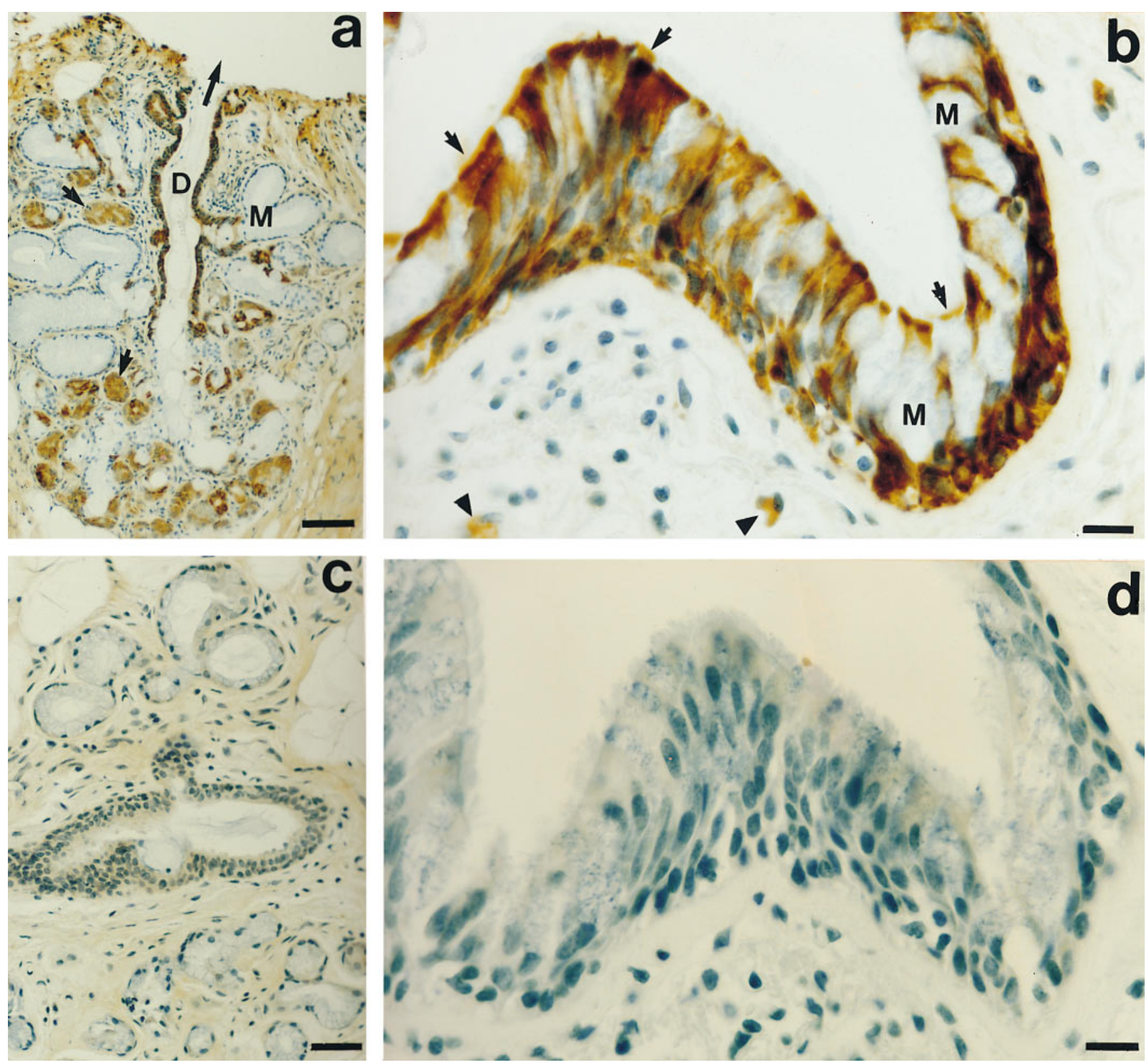

Figure 1. Matrilysin in conducting airways. (a) Immunostaining (peroxidase) for matrilysin was seen in epithelial cells lining the central duct $(D)$ of a peribronchial gland. In the acinar portion of the gland, matrilysin was detected in serous cells but not in any mucous cells $(M)$. Bar, $100 \mu \mathrm{m}$. (b) Columnar cells of the bronchial epithelium were positive for matrilysin protein whereas mucous goblet cells $(M)$ did not stain for the protein. Staining for matrilysin was also seen in the cilia layer of some cells, but no signal was seen in the underlying basement membrane. Matrilysin was also detected in occasional inflammatory cells (arrowheads). Bar, $25 \mu \mathrm{m}$. ( $c$ and $d$ ) No signal was seen in sections processed with preimmune serum $(c)$ or incubated with antimatrilysin antibody and excess peptide antigen $(d)$. Bar, $50 \mu \mathrm{m}$ for $c$ and $100 \mu \mathrm{m}$ for $d$.

showed no overt pathology and resembled those in normal lungs. In peribronchial glands, immunostaining was seen in ductal epithelial cells and secretory serous cells, whereas clear mucous cells showed no reactivity for matrilysin protein (Fig. 1a).

At all levels of the conducting airway, matrilysin was present in ciliated cells, whereas mucous cells, at least the mucous-containing vesicles, had no signal for matrilysin (Fig. 1b). Outside of the cells, no immunostaining was seen in the underlying basement membrane but staining was evident in the cilia layers of many cells (Fig. $1 b$, arrows). This localization suggests that constitutively produced matrilysin is secreted into the airway lumen (also see Fig. 4). No immunoreactivity was seen in sections processed with preimmune serum (Fig. 1c), and specific signal for matrilysin was blocked if sections were incubated with antibody and excess peptide antigen (Fig. $1 d$ ). Although signal for matrilysin mRNA colocalized to epithelial cells that stained for the protein, the in situ hybridization signal in normal lung was weak and seen only in occasional airway cells (Fig. 2, $a$ and $b$ ). Other than an occasional phagocyte (Fig. $1 \mathrm{~b}$, arrowheads), no signal for matrilysin protein or mRNA was seen in any other cell type in the lung.

Matrilysin is upregulated in $C F$. We next addressed if matrilysin expression is modulated in response to airway injury. 
In wounded skin, multiple MMPs, specifically collagenase-1, stromelysin-1, and $92-\mathrm{kD}$ gelatinase, but not matrilysin, are produced by keratinocytes in response to wounding $(7,30,36-$ $39)$. However, in a survey of numerous and diverse lung conditions, we never detected expression of these MMPs in any pulmonary epithelial cell, either in normal, inflamed, or diseased lung, with the exception of collagenase-1 expression in one area of damaged airway epithelium in one CF sample (data not shown).

Because matrilysin is constitutively produced in airway epithelium, we examined its production in biopsies of lungs from patients with $\mathrm{CF}$, a condition associated with extensive airway injury and obstruction. Compared with the same parameters in normal lung (Fig. 2, $a$ and $b$ ), expression of matrilysin mRNA and protein was markedly increased in the epithelium of upper airway epithelial cells of CF lungs (Fig. 2, $c-f$ ). Most obvious were the high levels of matrilysin mRNA expression seen in essentially all epithelial cells at sites of overt damage of airway epithelium (Fig. 2, $d$ and $f$ ). The findings shown in Fig. 2 were typical of all $12 \mathrm{CF}$ specimens examined. Expression of matrilysin in peribronchial glands did not differ noticeably between normal and CF lungs (data not shown).

Matrilysin is induced in alveolar epithelium in CF. The lining of the lung is divided into two functionally distinct epithelial compartments: the conducting epithelium of the upper airways and the respiratory epithelium of the lower bronchioles and alveoli. In all samples of normal lung (pulmonary hypertension and tumor-free margins), no expression of matrilysin was seen in the respiratory epithelium (Fig. $3 e$ ), but in all $\mathrm{CF}$ lungs examined $(n=12)$, prominent signal for matrilysin protein and mRNA was seen in alveolar type II pneumocytes (Fig. $3, a-d)$. These cells were identified as epithelial cells by posi-
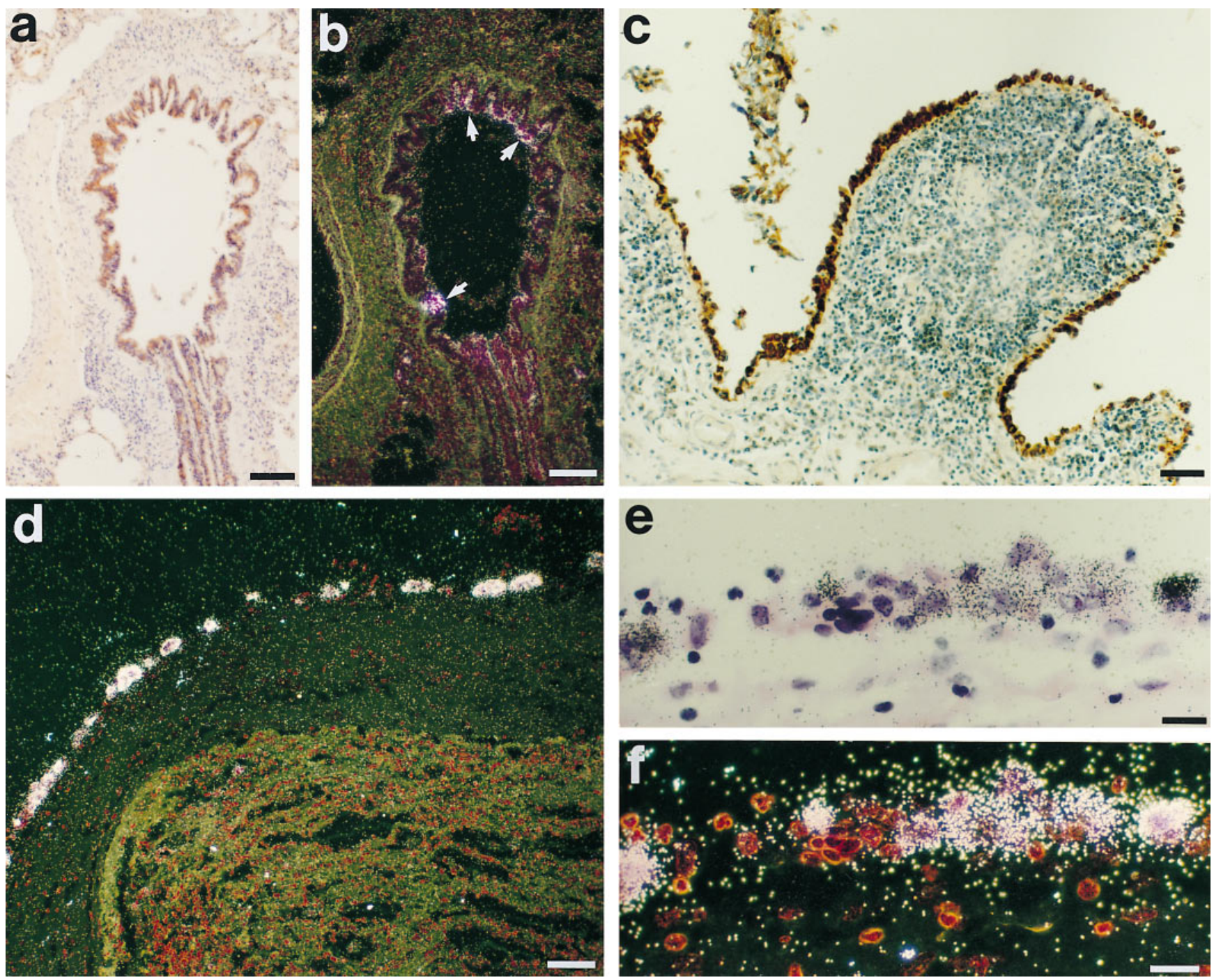

Figure 2. Upregulation of matrilysin in CF. (a) In lung from a patient with primary pulmonary hypertension, matrilysin protein (peroxidase immunostaining) is seen in bronchiolar epithelial cells. Bar, $100 \mu \mathrm{m}$. (b) In situ hybridization for matrilysin mRNA was done on a section serial to that shown in $a$. Weak autoradiographic signal was confined to a few bronchiolar epithelial cells. Autoradiographic exposure was for $21 \mathrm{~d}$. Bar, 100 $\mu \mathrm{m}$. (c) In a section of lung from a patient with CF, strong staining for matrilysin protein was seen in the damaged epithelium lining a highly inflamed conducting airway. Bar, $50 \mu \mathrm{m}$. (d) In situ hybridization showed strong autoradiographic signal for matrilysin mRNA in most airway epithelial cells. Autoradiographic exposure was for $21 \mathrm{~d}$. Bar, $50 \mu \mathrm{m}$. ( $e$ and $f$ ) Paired bright- and dark-field views of CF airway hybridized for matrilysin mRNA. Autoradiographic exposure was for $21 \mathrm{~d}$. Bar, $20 \mu \mathrm{m}$. 
tive staining for cytokeratin in serial sections (data not shown) and as type II cells by their location along alveolar walls and their characteristic oval shape (Fig. 3, $b-d$ ). In CF lung samples, matrilysin-positive type II pneumocytes were seen in areas with evidence of mild fibrosis and inflammation. No signal was seen on any section processed with preimmune serum or hybridized with a sense RNA (data not shown). In ongoing work, we have also detected expression of matrilysin in alveolar pneumocytes in areas of fibrosis in emphysematous lungs, in fibrotic lungs with diffuse alveolar damage, and in inflamed lungs of patients with idiopathic pneumonia syndrome after bone marrow transplantation (data not shown). However, in other forms of human lung disease studied for this report, which included pulmonary hypertension, organizing pneumonia, and sarcoidosis, no signal for matrilysin protein or mRNA was detected in alveolar epithelial cells (Fig. 3e).
Vectorial secretion of matrilysin. To begin to understand the function of matrilysin in lung epithelium, we determined the vectorial secretion of this MMP. Staining for matrilysin protein was seen in the cilia layer of human (data not shown) and rat airway epithelial cells and accumulated within the apical compartment of these cells (Fig. $4 A$ ). Similar to the lack of staining we noted in the bronchial basement membrane (Fig. 1b), these observations suggest that the matrilysin produced in intact tissue is secreted apically. Although matrilysin was not detected in alveolar cells in normal rat (data not shown) or human lung, primary rat type II cells do produce matrilysin in response to being placed in culture (Fig. $4 \mathrm{~B}$ ). In electrically resistant confluent monolayers, low levels of matrilysin were secreted by untreated cells, and all protein detected by casein zymography was in the apical transwell compartment (Fig. 4 $B)$. With PMA stimulation, matrilysin expression was mark-
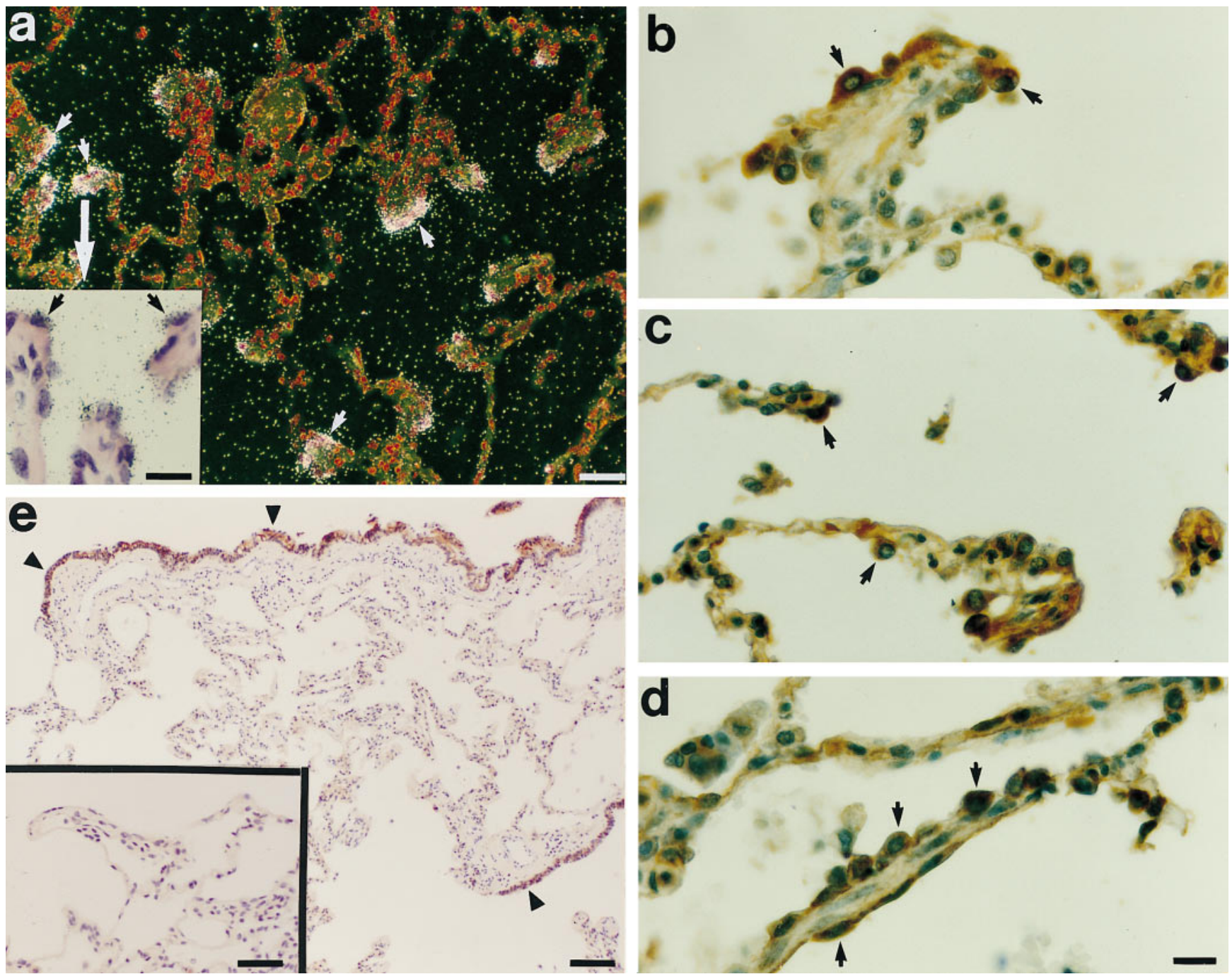

Figure 3. Matrilysin is induced in type II pneumocytes in CF. (a) In sections of human lung from patients with CF processed for in situ hybridization, prominent signal for matrilysin mRNA was seen in epithelial cells lining alveolar walls and septal tips (arrows). No signal was seen in any interstitial or inflammatory cells. Autoradiographic exposure was for $21 \mathrm{~d}$. Bar, $50 \mu \mathrm{m}$. Inset: bar, $20 \mu \mathrm{m}$. $(b-d)$ Immunohistochemistry (peroxidase) demonstrated prominent signal for matrilysin protein in numerous alveolar epithelial cells (arrows mark representative cells). No cells within the interstitial compartment stained for matrilysin protein. Bar, $15 \mu \mathrm{m}$. (e) In a section of peripheral lung from a patient with primary pulmonary hypertension, no staining for matrilysin was seen in alveoli but signal was predictably seen in the epithelium of a conducting airway (arrowheads). Bar, $240 \mu \mathrm{m}$. Inset: bar, $50 \mu \mathrm{m}$. 

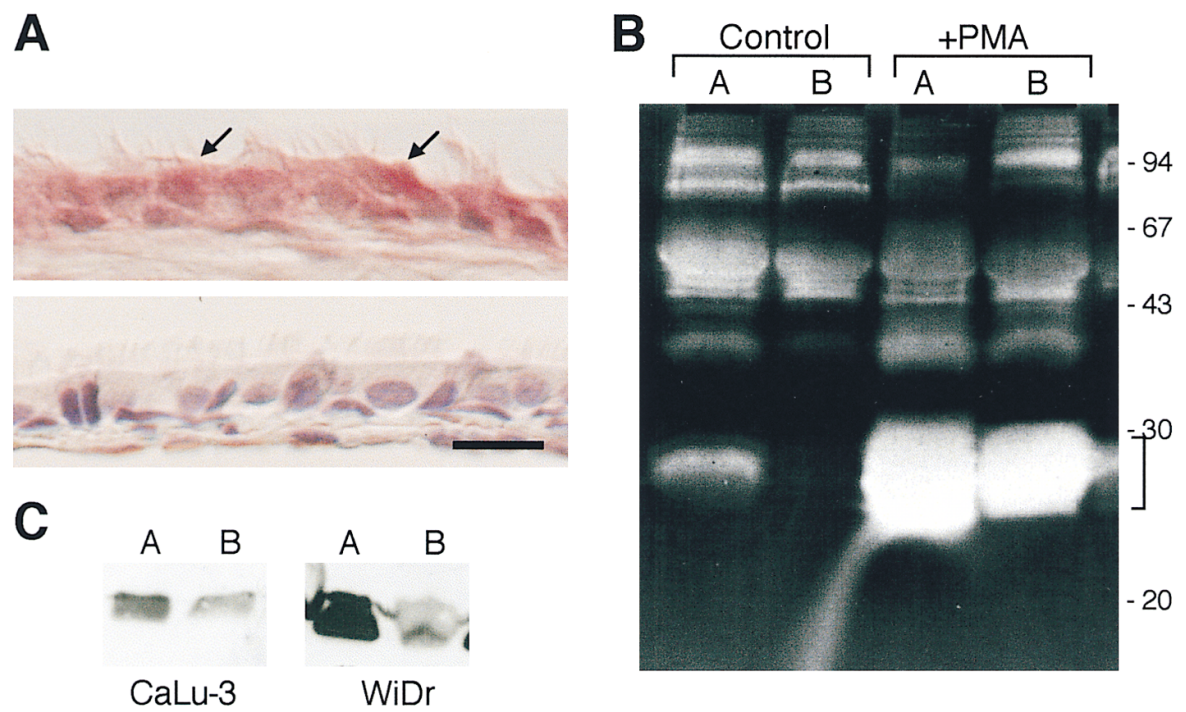

Figure 4. Vectorial secretion of matrilysin. (A) Immunostaining (alkaline phosphatase) for matrilysin was detected in the cilia layer of normal rat airway epithelium, and within the cells, stronger signal for enzyme was seen in the apical side (arrows). No immunoreactivity was observed in sections processed with preimmune serum (bottom). Both samples were photographed using Nomarski optics. Bar, 100 $\mu \mathrm{m}$. (B) Alveolar type II pneumocytes were plated onto transwell inserts, and the formation of a tight epithelial monolayer was assessed by measurement of electrical resistance. At $48 \mathrm{~h}$, conditioned medium was collected from both the upper ( $A$, apical) and lower ( $B$, basal) compartments from control and PMA-treated cells and analyzed by casein zymography. In control cells, the small amount of matrilysin secreted (marked by the open bracket) was

all released apically, but in response to PMA, markedly increased levels of matrilysin were secreted and about equal amounts were detected in both the apical and basal compartments. The caseinolytic bands migrating slower than matrilysin do not display regulated secretion or marked change in production to PMA. $(C)$ CaLu-3 and WiDr cells were plated onto transwell inserts, and the formation of a tight epithelial monolayer was assessed by measurement of electrical resistance. At $72 \mathrm{~h}$, conditioned medium was collected from both the upper $(A$, apical) and lower $(B$, basal) compartments and analyzed by Western blot. In both cell lines, matrilysin was secreted apically. Small amounts of matrilysin were detected in the basal compartment of both cell lines.

edly increased, and nearly equal levels of the proteinase were detected in both the basal and apical compartments (Fig. 4 B). As assessed with an ohmmeter, the resistance, and consequently the integrity of the monolayer, was not affected by treatment with PMA. The other caseinolytic bands were not altered by PMA and did not reveal regulated secretion towards either compartment.

To assess further the directional secretion of matrilysin, we analyzed enzyme release in CaLu-3 cells, a human lung adenocarcinoma cell line, and WiDr cells, a human colorectal adenocarcinoma cell line. Both cell lines were used since they constitutively express matrilysin and form electrically resistant monolayers. In both cell lines, the majority of matrilysin was selectively released apically into the upper chamber (Fig. $4 C$ ). Small amounts of basally secreted matrilysin were detected in medium from the lower compartment. These cell culture data, along with our in vivo observations, suggest that matrilysin functions in lumen of the upper airways in intact lung and that it can be delivered basally in response to injury or cell activation.

Matrilysin is expressed in injured trachea. To assess further the association of matrilysin in injury response of airway epithelium, we determined its expression in an ex vivo woundrepair model using normal adult human trachea. For this study, small, uniformly sized pieces of normal trachea were incubated for $0-5 \mathrm{~d}$ in culture medium. During this time, epithelial cells migrated over the edge of the cut surface in an attempt to heal the "wounded" tissue. In fresh trachea, low levels of matrilysin protein were seen in the airway epithelial cells and stronger staining was evident in ductal epithelial cells (Fig. 5, do). From days 1-5, airway epithelial cells at the margin of the tissue samples moved off the basement membrane (large arrows) and migrated progressively along the surface of the adjacent interstitial matrix (Fig. 5). In contrast to all airway epithelial cells in the day 0 sample and to the epithelium re- maining on the basement membrane in the later samples, prominent signal for matrilysin protein was seen in all epithelial cells that had migrated away from the wound edge (Fig. 5, $d 1, d 3$, and $d 5$ ). In all samples, a stronger signal for matrilysin protein was seen in migrating cells in contact with the underlying interstitial matrix than in cells in the migratory front without obvious contacts to the matrix. In addition, matrilysin was seen being released towards the matrix from some of these strongly positive cells (Fig. 5, d5). These findings support the idea that matrilysin functions in repair of the airway epithelium. In agreement with our in vivo findings, collagenase-1, stromelysin-1, and 92-kD gelatinase were not detected by immunohistochemistry or in situ hybridization in the epithelium of tracheal explants (data not shown).

Repair of tracheal epithelium requires MMP activity. Further evidence for a functional role of matrilysin in reepithelialization was obtained by using SC44463, a peptide hydroxamate inhibitor of MMP catalytic activity. This compound is a substrate-based inhibitor containing a hydroxamic acid moiety which chelates the active site zinc cation and renders MMPs catalytically inactive. SC44463 has a $K_{\mathrm{i}}$ of $\sim 1 \mathrm{nM}$ for pure MMPs in solution (34). Previously, we have used this inhibitor in our studies to demonstrate the dependence on collagenase- 1 activity for keratinocyte migration over a type I collagen substratum (2). Uniform wounds were made with a 1.5 -mm-wide cell scraper in the center of human tracheal explants, and specimens were kept in cell culture medium. At $24 \mathrm{~h}$ after injury, control epithelial wounds were $\sim 70 \%$ closed, whereas wounded tracheas cultured in the presence of SS44463 showed essentially no evidence of reepithelialization over the 24-h experiment (Fig. $6 \mathrm{~A}$ ). These data indicate that reepithelialization of airway wounds require the activity of MMPs. Because other MMPs, namely collagenase-1, stromelysin-1, and $92-\mathrm{kD}$ gelatinase, were not expressed by intact or injured tracheal epithelium, these data support a role for matrilysin in epithelial 


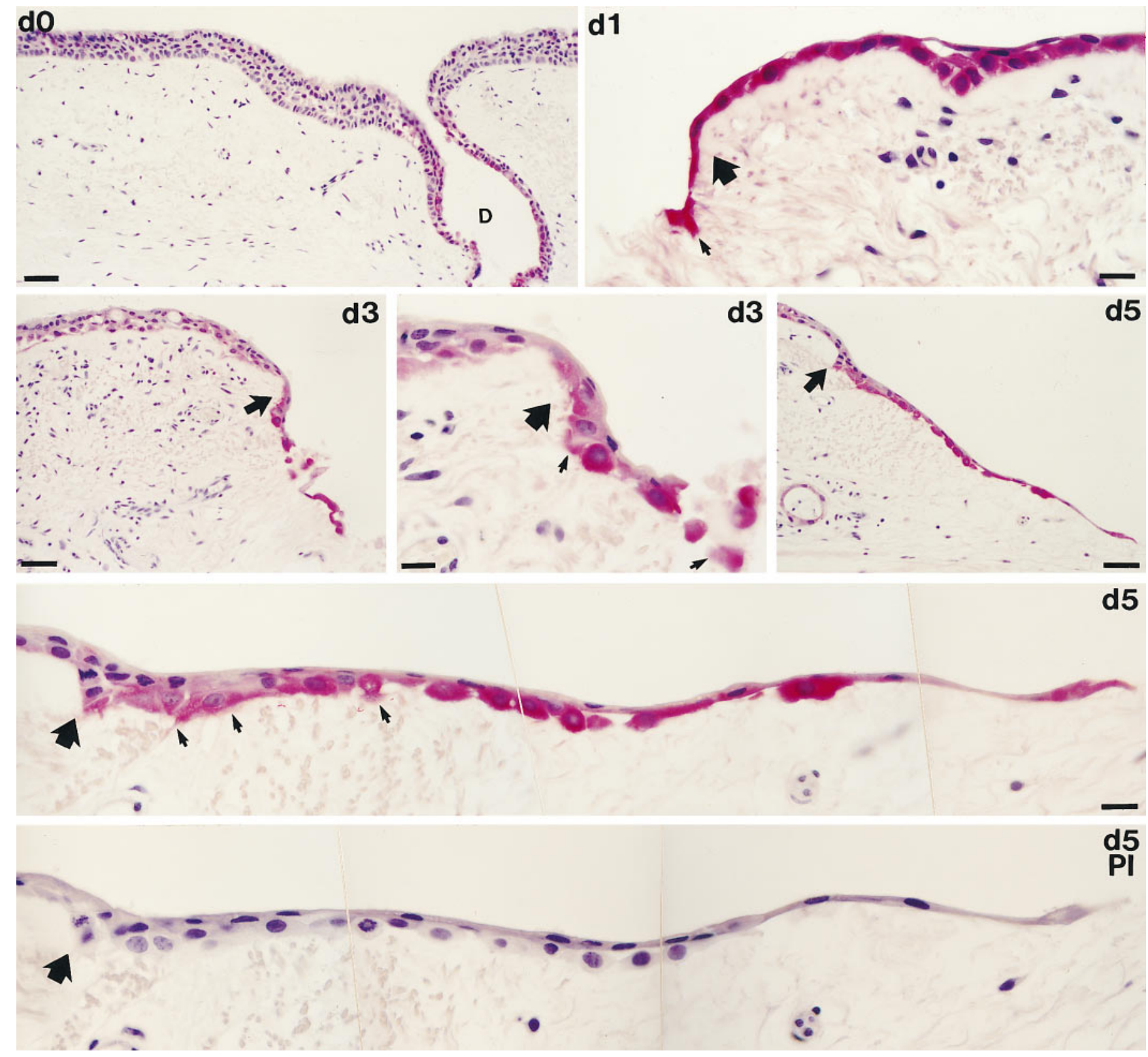

Figure 5. Upregulation of matrilysin in migrating tracheal epithelial cells. Sections of a segment of normal human trachea were incubated in culture medium at $37^{\circ} \mathrm{C}$ for $0,1,3$, or $5 \mathrm{~d}(d 0, d 1, d 3$, and $d 5)$ before fixation and immunohistochemistry (alkaline phosphatase). In $d 1, d 3$, and $d 5$, the large arrows mark the edge of the biopsy and the margin of basement membrane, which is seen as the clear area underlying the epithelium. In fresh tissue $(d 0)$, staining for matrilysin was seen in the ductal epithelium $(D)$ and weaker staining for the proteinase was seen in the tracheal epithelial cells. Over days 1-5 after plating, the epithelial cells migrated progressively, and intense staining for matrilysin was seen in these migrating cells, especially those in close contact with the underlying matrix. Release of matrilysin towards the matrix was seen in association with some cells (small arrows). No signal was seen in sections processed with preimmune serum (PI). Bar, $100 \mu \mathrm{m}$ for low magnification views and 20 $\mu \mathrm{m}$ for high magnification views.

cell migration after injury. However, because SC44463 blocks the catalytic activity of all MMPs, including other metalloenzymes, we needed more specific reagents to verify that matrilysin is needed for reepithelialization.

Tracheal reepithelialization is markedly impaired in matrilysin-null mice. As we saw in human tissue, matrilysin was expressed in airway epithelial cells that had migrated over the cut edges of dissected mouse tracheas (Fig. $7 a$ ). To specifically implicate matrilysin in airway reepithelialization, we wounded tracheas from wild-type and matrilysin-null mice using a 1.5mm-wide cell scraper, just as we did with the human specimens. In tracheas from wild-type mice, reepithelialization progressed rapidly and was nearly complete by $24 \mathrm{~h}$ after injury (Figs. $7 b$ and $6 \mathrm{~B}$ ). In contrast, wounds in tracheas from matrilysin-null mice showed no evidence of epithelial migration (Fig. $7 \mathrm{c}$ ), and the size of the wound opening did not change significantly over the 24-h course of the experiment (Fig. $6 \mathrm{~B}$ ). These same results were seen in tracheas from six 

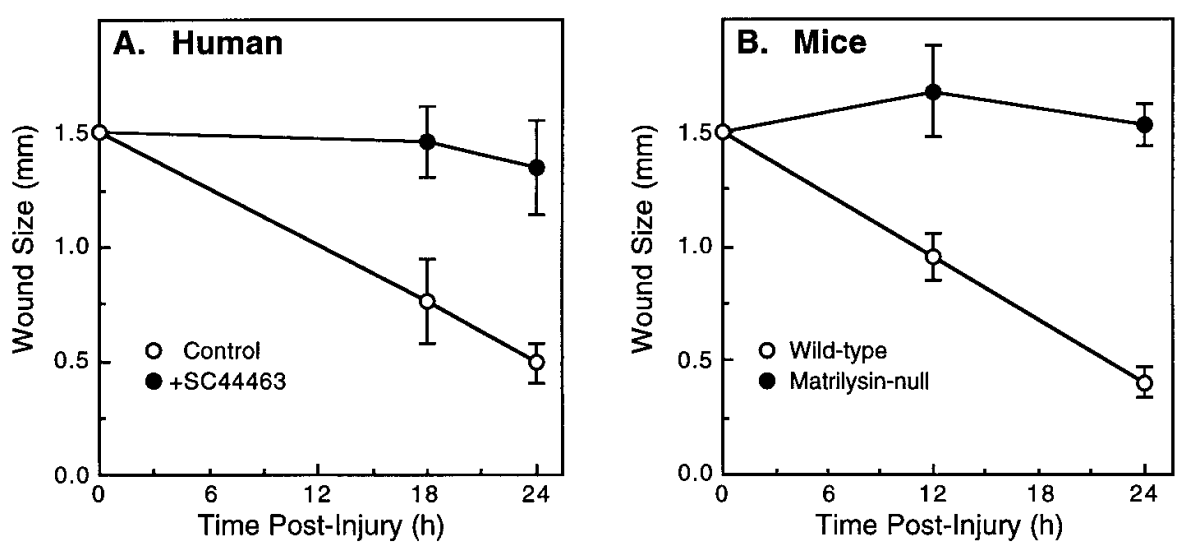

Figure 6. Reepithelialization is blocked by MMP inhibitor and in matrilysin-null mice. Normal human $(A)$ and matrilysin-null and wild-type mice $(B)$ trachea were isolated, wounded in their centers with a $1.5-\mathrm{mm}$ wide cell scraper, and processed for histology as described in Methods. Human explants were placed into culture medium and incubated at $37^{\circ} \mathrm{C}$ in the presence (+) or absence (-) of $25 \mu \mathrm{M}$ SC44463, an MMP hydroxamate inhibitor, for 18 or 24 h. For both human and mouse tissues, reepithelialization was quantified as the distance between opposing epithelial margins. For human trachea $(A)$, the data are the mean \pm SEM of four sections per time point from three separate tracheal pieces. For mice $(B)$, the data (mean \pm SEM) were collected from two experiments using three of each mouse line. mice of each line used in two experiments. These data indicate that matrilysin is needed for efficient reepithelialization of injured airway.

\section{Discussion}

A significant finding of our studies is that, distinct from other MMPs, matrilysin can be produced in intact lung tissue, specifically in peribronchial glands and conducting airways. In nondiseased and noninflamed tissues, expression of other metalloproteinases is generally limited to normal remodeling processes, such as the production of collagenase during cutaneous wound healing (7) and the expression of gelatinases and stromelysin-1 during peribronchial gland development (6), osteogenesis $(9,40)$, embryonic implantation (41), and breast lactation cycles $(42,43)$. Although the functional significance of constitutive expression of matrilysin in airways is not known, the observation that this enzyme is released apically indicates that it serves some function in the airway lumen. In addition to the transwell experiments (Fig. 4, $B$ and $C$ ), the lack of detectable immunostaining for matrilysin in the basement membrane of intact airway coupled with its presence in the cilia layer (Figs. $1 b$ and $4 A$ ) provides in vivo evidence that this MMP is preferentially released into the airway lumen in normal lung. We believe that this lack of staining in the basement membrane is significant and reliable because, as demonstrated in other studies, we are able to localize sites of MMP release in tissues, such as the secretion of collagenase- 1 from migrating keratinocytes into the underlying dermis (7) and the presence of immunoreactive $92-\mathrm{kD}$ gelatinase in the matrix surrounding neutrophil and eosinophil degranulation (44). Providing further evidence that it can be secreted apically, matrilysin has been detected in the lumen of glandular structures in intestinal adenomas (27).

Proteolytic activities have been found in exocrine secretions, including CF sputum (21, 45-47), and the function of these enzymes has often been thought to participate in maintaining flow. Thus, in addition to other potential functions, matrilysin may digest glycoproteins and membrane debris, thereby facilitating mucous flow. The broad and potent sub- strate specificity of matrilysin supports it as a reasonable candidate proteinase for fulfilling this biological function. If matrilysin does degrade proteins in the airway lumen, its activity would likely be limited to specific components. Indeed, in vitro studies have shown that surfactant protein $\mathrm{D}$ is resistant to catalysis by matrilysin (48). We examined matrilysin in CF with the idea that enzyme expression may be modulated in response to glandular obstruction, and we found that matrilysin expression was markedly upregulated in airway epithelium of all CF lung biopsies examined (Fig. 2). However, we cannot determine if matrilysin production in $\mathrm{CF}$ airways is stimulated by obstruction directly or by some other event or stimulus, such as injury, inflammation, infection, or soluble factors, although data in this report argue in favor of injury-dependent events.

Our data strongly suggest that one functional role of matrilysin after injury to upper airway epithelium is to facilitate epithelial cell migration. We observed that enzyme production was markedly upregulated in migrating tracheal epithelial cells ex vivo (Fig. 5), indicating that events directly related to injury, such as altered cell-matrix interactions or loss of cell-cell contacts, may control matrilysin production in wounded airway epithelium. To examine the biological function of matrilysin expression in response to injury, we assessed reepithelialization in wounded human trachea treated with an inhibitor of MMP activity (Fig. 6) and in wounded trachea from matrilysin-null mice (Figs. 6 and 7). The marked inhibition of tracheal reepithelialization in both models, but especially in the matrilysin knockout mice, indicates that the catalytic activity of matrilysin produced by migrating airway epithelial cells is necessary for cell migration after injury. We do not yet know if matrilysin is required for remodeling of a matrix component or for processing of some factor that may provoke cell proliferation or migration or for cleavage of cell surface molecules, such as integrins (49), to allow cell movement.

In addition to expression of matrilysin in upper airway epithelium and peribronchial glands, we report that this MMP was induced and prominently expressed by alveolar type II pneumocytes in lungs of patients with CF (Fig. 3), an expression pattern that we speculate occurs in response to alveolar 

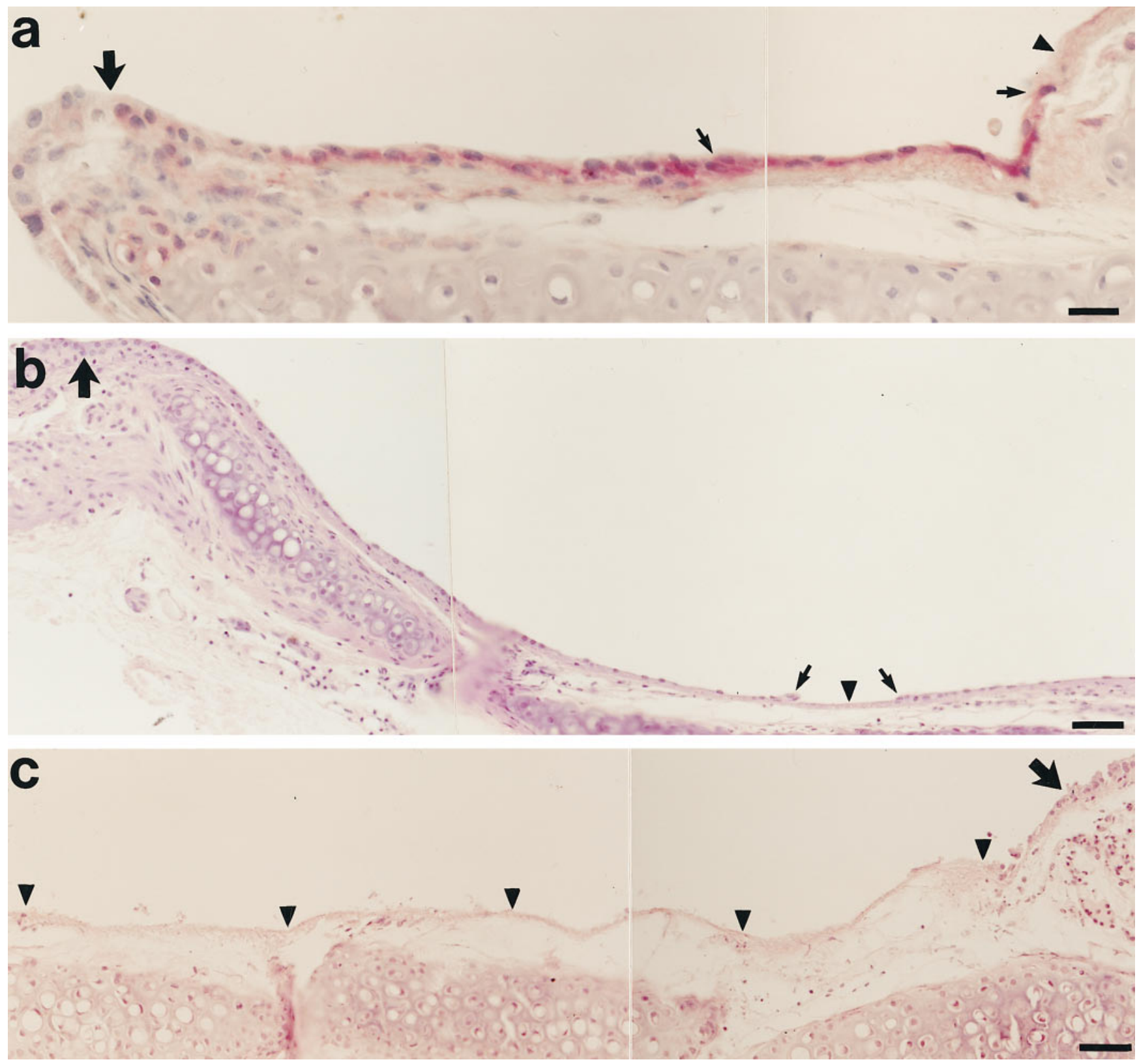

Figure 7. Tracheal reepithelialization is impaired in matrilysin-null mice. (a) Tracheas from wild-type mice were removed, cut into pieces, and cultured for $3 \mathrm{~d}$ before fixation and immunohistochemistry (alkaline phosphatase). Strong expression of matrilysin was seen in airway epithelial cells that had migrated from the wound edge onto the interstitial matrix (small arrows). The large arrow marks the cut edge of the tissue sample, and the arrowhead points to a "denuded" area of the interstitium. Bar, $25 \mu \mathrm{m}$. (b) Tracheas from wild-type mice were splayed, injured on their epithelial surface with a cell scraper, and cultured for 12 or $24 \mathrm{~h}$ before fixation and immunohistochemistry (alkaline phosphatase). At $24 \mathrm{~h}$ after injury, wounds in tracheas from wild-type mice were nearly completely closed. The large arrow indicates the edge of one side of the original wound; the other side of the wound is off the field-of-view. Small arrows denote the two advancing migrating fronts, and the arrowhead indicates the remaining denuded wound. Bar, $100 \mu \mathrm{m}$. (c) At $24 \mathrm{~h}$ after injury, wounds in tracheas from matrilysin-null mice remained open with little evidence of reepithelialization. The large arrow indicates the edge of one side of the wound. Arrowheads mark the long denuded wound. Bar, $100 \mu \mathrm{m}$.

injury. Distal lung injury is usually followed by the death of type I pneumocytes, which line the alveolar surface and are responsible for gas exchange. Quantitatively, type II pneumocytes comprise most of the alveolar epithelium, although type I cells occupy a much larger area. Relevant to our observations, type II epithelial cells are the physiologically competent alveolar cells that respond to injury. They produce cytokines, and they are responsible for restoring alveolar morphology by synthesizing and depositing a basement membrane and by proliferating and differentiating into type I cells (50). We have found that MMPs, such as collagenase- 1 in the basal epidermis $(7,51)$ and matrilysin in intestinal epithelium $(26)$, are expressed by epithelial cells in response to injury. Thus, induction of metalloproteinases is a common and seemingly required response of epithelial cells involved in repair processes, and matrilysin is apparently a major, if not the predominant, MMP used by in- 
jured lung cells. Although stromelysins- 1 and -2 and $92-\mathrm{kD}$ gelatinase are expressed by respiratory epithelial cells and in type II cells in culture under a variety of conditions (52-56), we have not detected expression of these enzymes by airway or alveolar epithelial cells in any in vivo or ex vivo tissue sample. Gelatinase A (MMP-2) is also expressed by alveolar type II cells in human lung (13), and it may also be involved in repair mechanisms.

We do not yet know the signals that mediate induction of matrilysin in injured lung epithelium. In wounded skin, we have found that collagenase- 1 is induced in basal keratinocytes as the cells move from the basement membrane onto the dermal matrix and that this response is specifically mediated by contact with native type I collagen via the integrin $\alpha_{2} \beta_{1}(2,57)$. Similarly, changes in cell-matrix interactions could modulate matrilysin expression by tracheal epithelial cells. In addition to the programmed responses of differentiated cells, the constitutive make-up of matrix receptors on an epithelial cell and the composition of the underlying interstitial matrix may dictate the pattern of MMP expression among epithelia. Thus, whereas collagenase- 1 facilitates migration of keratinocytes over the collagen-rich matrix of dermis, matrilysin would be a more appropriate proteinase to remodel airway wall matrix components, which include elastin, adhesive glycoproteins, and proteoglycans. The regulated secretion of matrilysin supports the idea that this epithelial MMP acts on matrix proteins during repair. Stimulation of matrilysin expression in response to wounding may be accompanied by regulation of the pathways controlling proenzyme sorting and vectorial secretion, thereby assuring that the proteinase is released at sites of matrix remodeling and cell migration. The presence of immunoreactive matrilysin underneath migrating tracheal epithelial cells (Fig. 5) but not in the basement membrane of intact airways (Fig. 1) supports this hypothesis.

Whereas cell-matrix interactions may influence the qualitative pattern of metalloproteinase expression among the epithelial cells of different tissues, the quantitative expression may be governed by other factors, such as cytokines or other proinflammatory mediators. Matrilysin is stimulated in monocytes by lipopolysaccharide (20), which is found in high concentration in CF sputum (58) and, hence, may modulate proteinase expression by resident lung cells. Only a few cytokines have been tested for their ability to influence matrilysin expression $(15,20,59)$. Because numerous proinflammatory mediators are present in CF lungs $(58,60)$, it is possible that matrilysin is induced in type II cells or upregulated in airway epithelium in response to one or more of these.

Matrilysin may serve both beneficial and harmful roles in $\mathrm{CF}$. Interestingly, the clinical abnormalities in $\mathrm{CF}$ are manifested in airways, sweat glands, intestine, and pancreas (61), which are among the same tissues in which we detected expression of matrilysin $(15,23,24)$. As discussed, the continual expression of matrilysin in upper airways and glands may provide proteolytic activity needed to facilitate the movement of material up the airways. The induction of this MMP in type II pneumocytes in CF may represent a response to chronic obstruction to provide the lung with more proteinase. Alternatively, matrilysin may be aberrantly turned on in CF and may contribute to alveolar wall damage. More generally, matrilysin expression by type II pneumocytes may accompany severe alveolar injury, and the proteolytic activity of this MMP may be needed to facilitate cell migration and repair. Regardless, matrilysin appears to be the predominant MMP expressed by lung epithelium after injury and may play a key role in tissue repair processes.

\section{Acknowledgments}

We thank Dr. Alec Patterson, Washington University, for samples of normal human trachea; Dr. E.C. Crouch, Washington University, for assistance in examining tissue specimens; and Heidi Haagen, Qinglang Li, Darlene Stewart, Teresa Tolley, and Lihua Yin for excellent technical assistance.

This work was supported by grants from the National Institutes of Health, by a Genentech/American Lung Association Career Investigator Award (W.C. Parks), and by the Council for Tobacco Research, USA, Inc. Sarah Dunsmore is supported as a Lucille P. Markey Postdoctoral Fellow.

\section{References}

1. Mignatti, P., D.B. Rifkin, H.G. Welgus, and W.C. Parks. 1996. Proteinases and tissue remodeling. In The Molecular and Cellular Biology of Wound Repair. 2nd edition. R.A.F. Clark, editor. Plenum Press, New York. 427-474.

2. Pilcher, B.K., J.A. Dumin, B.D. Sudbeck, S.M. Krane, H.G. Welgus, and W.C. Parks. 1997. The activity of collagenase-1 is required for keratinocyte migration on a type I collagen matrix. J. Cell Biol. 137:1445-1457.

3. Woessner, J.F., Jr. 1998. The matrix metalloproteinase family. In Matrix Metalloproteinases. W.C. Parks and R.P. Mecham, editors. Academic Press, Inc., San Diego. 1-14.

4. Birkedal-Hansen, H., W.G.I. Moore, M.K. Bodden, L.J. Windsor, B. Birkedal-Hansen, A. DeCarlo, and J.A. Engler. 1993. Matrix metalloproteinases: a review. Crit. Rev. Oral Biol. Med. 4:197-250.

5. Matrisian, L.M. 1992. The matrix-degrading metalloproteinases. BioEssays. $14: 455-463$.

6. Tournier, J.M., M. Polette, J. Hinnrasky, J. Beck, Z. Werb, and C. Basbaum. 1994. Expression of gelatinase A, a mediator of extracellular matrix remodeling, by tracheal gland serous cells in culture and in vivo. J. Biol. Chem. 269:25454-25464

7. Saarialho-Kere, U.K., S.O. Kovacs, A.P. Pentland, J. Olerud, H.G. Welgus, and W.C. Parks. 1993. Cell-matrix interactions modulate interstitial collagenase expression by human keratinocytes actively involved in wound healing. J. Clin. Invest. 92:2858-2866.

8. Rodgers, W.H., K.G. Osteen, L.M. Matrisian, M. Navre, L.C. Giudice, and F. Gorstein. 1993. Expression and localization of matrilysin, a matrix metalloproteinase, in human endometrium during the reproductive cycle. Am.J. Obstet. Gynecol. 168:253-260.

9. Chin, J.R., and Z. Werb. 1997. Matrix metalloproteinases regulate morphogenesis, migration and remodeling of epithelium, tongue skeletal muscle and cartilage in the mandibular arch. Development. 124:1519-1530.

10. Brinckerhoff, C.E. 1991. Joint destruction in arthritis: metalloproteinases in the spotlight. Arthritis Rheum. 34:1073-1075.

11. Libby, P. 1995. Molecular bases of the acute coronary syndromes. Circulation. 91:2844-2850.

12. Halpert, I., J.D. Roby, U.I. Sires, S. Potter-Perigo, T.N. Wight, H.G. Welgus, S.D. Shapiro, S.A. Wickline, and W.C. Parks. 1996. Matrilysin is expressed by lipid-laden macrophages at sites of potential rupture in atherosclerotic lesions and localizes to areas of versican deposition, a proteoglycan substrate for the enzyme. Proc. Natl. Acad. Sci. USA. 93:9748-9753.

13. Hayashi, T., W.G. Stetler-Stevenson, M.V. Fleming, N. Fishback, M.N. Koss, L.A. Liotta, V.J. Ferrans, and W.D. Travis. 1996. Immunohistochemical study of metalloproteinases and their tissue inhibitors in the lungs of patients with diffuse alveolar damage and idiopathic pulmonary fibrosis. Am. J. Pathol. 149:1241-1256.

14. Parks, W.C. 1995. The production, role, and regulation of matrix metalloproteinases in the healing epidermis. Wounds: A Compendium of Clinical Research and Practice. Vol. 7. 23A-37A.

15. Wilson, C.L., and L.M. Matrisian. 1998. Matrilysin. In Matrix Metalloproteinases. W.C. Parks and R.P. Mecham, editors. Academic Press, Inc., San Diego. 149-184.

16. Sires, U.I., G.L. Griffin, T. Broekelmann, R.P. Mecham, G. Murphy, A.E. Chung, H.G. Welgus, and R.M. Senior. 1993. Degradation of entactin by matrix metalloproteinases. Susceptibility to matrilysin and identification of cleavage sites. J. Biol. Chem. 268:2069-2074.

17. Murphy, G., M.I. Cockett, R.V. Ward, and A.J.P. Docherty. 1991. Matrix metalloproteinase degradation of elastin, type IV collagen and proteoglycan. A quantitative comparison of the activities of $95 \mathrm{kD}$ and $75 \mathrm{kD}$ gelatinases, stromelysins-1 and -2 and punctuated metalloproteinase (PUMP). Biochem. J. 277:277-279. 
18. Sires, U.I., G. Murphy, V.M. Baragi, C.J. Fliszar, H.G. Welgus, and R.M. Senior. 1994. Matrilysin is much more efficient than other metalloproteinases in the proteolytic inactivation of $\alpha-1$ antitrypsin. Biochem. Biophys. Res. Commun. 204:613-620.

19. Busiek, D.F., F.P. Ross, S. McDonnell, G. Murphy, L.M. Matrisian, and H.G. Welgus. 1992. The matrix metalloprotease matrilysin (PUMP) is expressed in developing human mononuclear phagocytes. J. Biol. Chem. 13:9087-9092.

20. Busiek, D.F., V. Baragi, L.C. Nehring, W.C. Parks, and H.G. Welgus. 1995. Matrilysin expression by human mononuclear phagocytes and its regulation by cytokines and hormones. J. Immunol. 154:6484-6491.

21. Wilson, M.J., B. Garcia, M. Woodson, and A.A. Sinha. 1992. Metalloproteinase activities expressed during development and maturation of the rat prostatic complex and seminal vesicles. Biol. Reprod. 47:683-691.

22. Rodgers, W.H., L.M. Matrisian, L.C. Giudice, B. Dsupin, P. Cannon, C. Svitek, F. Gorstein, and K.G. Osteen. 1994. Patterns of matrix metalloproteinase expression in cycling endometrium imply differential functions and regulation by steroid hormones. J. Clin. Invest. 94:946-953.

23. Saarialho-Kere, U.K., E.C. Crouch, and W.C. Parks. 1995. Matrix metalloproteinase matrilysin is constitutively expressed in human exocrine epithelium. J. Invest. Dermatol. 105:190-196.

24. Wilson, C.L., K.J. Heppner, L.A. Rudolph, and L.M. Matrisian. 1995. The metalloproteinase matrilysin is preferentially expressed by epithelial cells in a tissue-restricted pattern in the mouse. Mol. Biol. Cell. 6:851-869.

25. Karelina, T.V., G.I. Goldberg, and A.Z. Eisen. 1994. Matrilysin (PUMP) correlates with dermal invasion during appendageal development and cutaneous neoplasia. J. Invest. Dermatol. 103:482-487.

26. Saarialho-Kere, U.K., M. Vaalamo, M.-L. Karjalainen-Lindsberg, K. Airola, W.C. Parks, and P. Puolakkainen. 1996. Enhanced expression of matrilysin, collagenase, and stromelysin-1 in gastrointestinal ulcers. Am. J. Pathol. 148:519-526.

27. Wilson, C.L., K.J. Heppner, P.A. Labosky, B.L.M. Hogan, and L.M. Matrisian. 1997. Intestinal tumorigenesis is suppressed in mice lacking the metalloproteinase matrilysin. Proc. Natl. Acad. Sci. USA. 94:1402-1407.

28. Muller, D., R. Breathnach, A. Engelmann, R. Millon, G. Bronner, H. Flesch, P. Dumont, M. Eber, and J. Abecassis. 1991. Expression of collagenaserelated metalloproteinase genes in human lung or head and neck tumours. Int. J. Cancer. 48:550-556.

29. Urbanski, S.J., D.R. Edwards, A. Maitland, K.J. Leco, A. Watson, and A.E. Kossakowska. 1992. Expression of metalloproteinases and their inhibitors in primary pulmonary carcinomas. Br. J. Cancer. 66:1184-1194.

30. Saarialho-Kere, U.K., S.O. Kovacs, A.P. Pentland, W.C. Parks, and H.G. Welgus. 1994. Distinct populations of keratinocytes express stromelysin-1 and -2 in chronic wounds. J. Clin. Invest. 94:79-88.

31. McDonnell, S., M. Navre, R.J. Coffrey, and L.M. Matrisian. 1991. Expression and localization of the matrix metalloproteinase Pump-1 (MMP-7) in human gastric and colon carcinomas. Mol. Carcin. 4:527-533.

32. Prosser, I.W., K.R. Stenmark, M. Suthar, E.C. Crouch, R.P. Mecham, and W.C. Parks. 1989. Regional heterogeneity of elastin and collagen gene expression in intralobar arteries in response to hypoxic pulmonary hypertension as demonstrated by in situ hybridization. Am. J. Pathol. 135:1073-1088.

33. Ståhle-Bäckdahl, M., and W.C. Parks. 1993. $92 \mathrm{kD}$ gelatinase is actively expressed by eosinophils and secreted by neutrophils in invasive squamous cell carcinoma. Am. J. Pathol. 142:995-1000.

34. Moore, W.M., and C.A. Spilburg. 1986. Purification of human collagenases with a hydroxamic acid affinity column. Biochemistry. 25:5189-5195.

35. Rannels, S.R., and D.E. Rannels. 1994. Isolation and culture of type II pulmonary epithelial cells. In Cell Biology: A Laboratory Handbook. J.E. Celis, editor. Academic Press, Inc., Orlando. 116-123.

36. Saarialho-Kere, U.K., E.S. Chang, H.G. Welgus, and W.C. Parks. 1993. Expression of interstitial collagenase, $92 \mathrm{kD}$ gelatinase, and TIMP-1 in granuloma annulare and necrobiosis lipoidica diabeticorum. J. Invest. Dermatol. 100: $335-342$

37. Saarialho-Kere, U.K., M. Vaalamo, K. Airola, K.-M. Niemi, A.I. Oikarinen, and W.C. Parks. 1995. Interstitial collagenase is expressed by keratinocytes which are actively involved in re-epithelialization in blistering skin diseases. J. Invest. Dermatol. 104:982-988.

38. Inoue, M., G. Kratz, A. Haegerstrand, and M. Ståhle-Bäckdahl. 1995. Collagenase expression is rapidly induced in wound-edge keratinocytes after acute injury in human skin, persists during healing, and stops at re-epithelialization. J. Invest. Dermatol. 104:479-483.

39. Salo, T., M. Mäkela, M. Kylmäniemi, H. Autio-Harmainen, and H. Larjava. 1994. Expression of matrix metalloproteinase-2 and -9 during early human wound healing. Lab. Invest. 70:176-182.

40. Vu, T.H., J.M. Shipley, G. Bergers, J.E. Berger, J.A. Helms, D. Hanahan, S.D. Shapiro, R.M. Senior, and Z. Werb. 1998. MMP-9/gelatinase B is a key regulator of growth plate angiogenesis and apoptosis of hypertrophic chondrocytes. Cell. 93:411-422.

41. Librach, C.L., Z. Werb, M.L. Fitzgerald, K. Chiu, N.M. Corwin, R.A Esteves, D. Grobelny, R. Galardy, C.H. Damsky, and S.J. Fisher. 1991. 92-kD type IV collagenase mediates invasion of human cytotrophoblasts. J. Cell Biol. 113:437-449.

42. Monteagudo, C., M.J. Merino, J. San-Juan, L.A. Liotta, and W.G. Stetler-Stevenson. 1990. Immunohistochemical distribution of type IV collagenase in normal, benign, and malignant breast tissue. Am. J. Pathol. 136:585-592

43. Talhouk, R.S., J.R. Chin, E.N. Unemori, Z. Werb, and M.J. Bissell. 1991. Proteinases of the mammary gland: developmental regulation in vivo and vectorial secretion in culture. Development. 112:439-449.

44. Ståhle-Bäckdahl, M., M. Inoue, G.J. Giudice, and W.C. Parks. 1994. $92-$ $\mathrm{kD}$ gelatinase is produced by eosinophils at the site of blister formation in bullous pemphigoid and cleaves the extracellular domain of the 180-kD bullous pemphigoid autoantigen. J. Clin. Invest. 93:2202-2230.

45. Wilson, M.J., M. Strasser, M.M. Vogel, and A.A. Sinha. 1991. Calciumdependent and calcium-independent gelatinolytic proteinase activities of the rat ventral prostate and its secretion: characterization and effect of castration and testosterone treatment. Biol. Reprod. 44:776-785.

46. Yin, H.-Z., M.M. Vogel, M. Schneider, C. Ercole, G. Zhang, A.A Sinha, and M.J. Wilson. 1990. Gelatinolytic proteinase activities in human seminal plasma. Reprod. Fert. 88:491-501.

47. Delacourt, C., M. Le Bourgeois, M.P. D'Ortho, C. Doit, P. Scheinmann, J. Navarro, A. Harf, D.J. Hartmann, and C. Lafuma. 1995. Imbalance between $95 \mathrm{kD}$ type IV collagenase and tissue inhibitor of metalloproteinases in sputum of patients with cystic fibrosis. Am. J. Respir. Crit. Care Med. 152:765-774.

48. Brown-Augsburger, P., K. Hartshorn, D. Chang, K. Rust, C. Fliszar, H.G. Welgus, and E.C. Crouch. 1996. Site-directed mutagenesis of Cys-15 and Cys-20 of pulmonary surfactant protein D. Expression of a trimeric protein with altered anti-viral properties. J. Biol. Chem. 271:13724-13730.

49. von Bredow, D.C., R.B. Nagle, G.T. Bowden, and A.E. Cress. 1997. Cleavage of $\beta 4$ integrin by matrilysin. Exp. Cell Res. 236:341-345.

50. Rennard, S.I., P.B. Bitterman, and R.G. Crystal. 1983. Response of the lower respiratory tract to injury. Mechanisms of repair of the parenchymal cells of the alveolar wall. Chest. 84:735-739.

51. Saarialho-Kere, U.K., E.S. Chang, H.G. Welgus, and W.C. Parks. 1992 Distinct localization of collagenase and TIMP expression in wound healing associated with ulcerative pyogenic granuloma. J. Clin. Invest. 90:1952-1957.

52. Yao, P.M., J.M. Buhler, M.P. d'Ortho, F. Lebargy, C. Delclaux, A. Harf, and C. Lafuma. 1996. Expression of matrix metalloproteinase gelatinases A and B by cultured epithelial cells from human bronchial explants. J. Biol. Chem. 271:15580-15589.

53. d'Ortho, M.P., C. Clerici, P.M. Yao, C. Delacourt, C. Delclaux, M.L. Franco-Montoya, A. Harf, and C. Lafuma. 1997. Alveolar epithelial cells in vitro produce gelatinases and tissue inhibitor of matrix metalloproteinases. $\mathrm{Am}$. J. Physiol. 273:L663-L675.

54. Buisson, A.C., C. Gilles, M. Polette, J.M. Zhan, P. Birembaut, and J.M Tournier. 1996. Wound repair-induced expression of a stromelysin is associated with the acquisition of a mesenchymal phenotype in human respiratory epithelial cells. Lab. Invest. 74:658-669.

55. Pardo, A., K. Ridge, B. Uhal, J.I. Sznajder, and M. Selman. 1997. Lung alveolar epithelial cells synthesize interstitial collagenase and gelatinases A and B in vitro. Int. J. Biochem. Cell Biol. 29:901-910.

56. Yao, P.M., C. Delclaux, M.P. D'Ortho, B. Maitre, A. Harf, and C. Lafuma. 1998. Cell-matrix interactions modulate 92-kD gelatinase expression by human bronchial epithelial cells. Am. J. Respir. Cell Mol. Biol. 18:812-822.

57. Sudbeck, B.D., B.K. Pilcher, H.G. Welgus, and W.C. Parks. 1997. Induction and repression of collagenase- 1 by keratinocytes is controlled by distinct components of different extracellular matrix compartments. J. Biol. Chem. 272: 22103-22110.

58. Wilmott, R.W., M. Frenzke, V. Kociela, and L. Peng. 1994. Plasma interleukin-1 alpha and beta, tumor necrosis factor-alpha, and lipopolysaccharide concentrations during pulmonary exacerbations of cystic fibrosis. Pediatr. Pulmonol. 18:21-27.

59. Klein, R.D., A.H. Borchers, P. Sundareshan, C. Bougelet, M.R. Berkman, R.B. Nagle, and G.T. Bowden. 1997. Interleukin-1 $\beta$ secreted from monocytic cells induces the expression of matrilysin in the prostatic cell line LNCaP. J. Biol. Chem. 272:14188-14192.

60. Kronborg, G., M.B. Hansen, M. Svenson, A. Fomsgaard, N. Hoiby, and K. Bendtzen. 1993. Cytokines in sputum and serum from patients with cystic fibrosis and chronic Pseudomonas aeruginosa infection as markers of destructive inflammation in the lungs. Pediatr. Pulmonol. 15:292-297.

61. Quinton, P.M. 1990. Cystic fibrosis: a disease in electrolyte transport FASEB (Fed. Am. Soc. Exp. Biol.) J. 4:2709-2717. 